ljtihad, Jurnal Wacana Hukum Islam dan Kemanusiaan

Vol. 17, No. 1 (2017), pp. 85-112, doi : 10.18326/ijtihad.v17i1.85-112

\title{
Penerapan nilai toleransi antar budaya dalam pelaksanaan hukum kewarisan Islam pada masyarakat perbatasan di Rao Pasaman Sumatera Barat
}

\author{
Nofiardi dan Syafwan Rozi \\ Institut Agama Islam Negeri Bukittinggi Sumatera Barat \\ E-mail: sya_ra_de@yahoo.co.id; noviardi_dz@yahoo.com \\ DOI: $10.18326 /$ ijtihad.v17i1.85-112
}

The Rao community on the border of West Sumatra inhabited by ethnic Minangkabau and ethnic Mandailing is a plural society that embraces two kinship systems. The patrilineal, the matrilineal, and the parent. But in the process of their interaction for decades there has been interaction through cultural tolerance in the kinship system. Here the birth of a parental kinship and familial system is the most dominant character in this multi ethnic Rao region as a new kinship system built in their social interaction process for hundreds of years. This system also affects the inheritance division system in their interactions. As for the inheritance distribution system, indigenous peoples of the border, especially the Rao area, have applied several types of inheritance distribution: First, Rao customary people use the new customary law of parental system which combines two customs as the first spear in determining inheritance. Second, they use Islamic law, because the Minangkabau and Mandailing are Moslems, so they use Islamic law in the inheritance. Third, they use national law, because if customary law and Islamic law do not want to be used then they use national law. These three systems are all intercultural tolerance amid differences in their customary system between Minangkabau adat matrineal system and Mandailing custom patrineal system.

Masyarakat Rao di perbatasan Sumatera Barat yang dihuni oleh etnik Minangkabau dan etnik Mandailing merupakan masyarakat plural yang menganut dua sistem kekerabatan. yakni golongan masyarakat yang bersifat kebapakan (patrilineal), masyarakat yang bersifat keibuan (matrilineal), dan golongan yang bersifat kebapak ibuan (parental). Namun dalam proses interaksi mereka selama puluhan tahun telah terjadi interaksi melalui toleransi budaya dalam system kekerabatan. Di sini lahir system kekerabatan dan kekeluargaan yang bersifat parental merupakan sifat yang paling dominan di daerah multi etnik Rao ini sebagai sebuah system kekerabatan baru yang dibangun dalam proses interaksi sosial mereka selama 
ljtihad, Jurnal Wacana Hukum Islam dan Kemanusiaan, Volume 17, No. 1, Juni 2017: 85-112

ratusan tahun. Sistem ini juga mempengaruhi system pembagian kewarisan dalam interaksi mereka. Adapun dalam system pembagian waris, masyarakat adat perbatasan terutama daerah Rao telah menerapkan beberapa jenis pembagian waris yaitu: Pertama, Masyarakat adat perbatasan Rao memakai hukum adat baru system parental yang memadukan dua adat sebagai tombak pertama dalam menentukan waris. Kedua, mereka memakai hukum Islam, sebab suku Minangkabau dan Mandailing adalah pemeluk agama Islam, maka mereka memakai hukum Islam dalam pewarisan. Ketiga, mereka memakai hukum nasional, sebab bila hukum adat dan hukum Islam tidak ingin dipakai maka mereka memakai hukum nasional. Ketiga system ini merupakan semacan toleransi antar budaya di tengah perbedaan system adat yang mereka anut antara system matrineal adat Minangkabau dan system patrineal adat Mandailing.

\section{Keywords: inheritance distribution; Inter-culture tolerance; Frontier Community}

\section{Pendahuluan}

Bangsa Indonesia memiliki keragaman suku dan budaya. Letak geografis Indonesia yang berbentuk kepulauan menyebabkan perbedaan kebudayaan yang mempengaruhi pola hidup dan tingkah laku masyarakat. Hal ini dapat dilihat pada suku-suku yang terdapat di Indonesia, di antaranya adalah suku Minang, Mandailing dan suku Jawa. Minangkabau merupakan suatu tempat di Indonesia di mana orang dapat menjumpai masyarakat yang disusun dan diatur menurut ibu. Mulai dari lingkungan hidup yang paling bawah seperti keluarga, sampai kepada lingkungan hidup yang paling atas, yaitu sebuah nagari dapat dilihat bahwa faktor turunan menurut garis ibu merupakan faktor yang mengatur organisasi masyarakatnya.

Kehidupan yang diatur menurut ibu itulah yang disebut dalam istilah sehari-hari sebagai kehidupan menurut adat. Istilah adat biasanya digabungkan dengan istilah lain, yaitu hukum, sehingga menimbulkan terjemahan istilah baru yaitu "hukum adat" (Anwar, 1997: 2). Hukum adat merupakan hukum yang tidak tertulis dan hidup di dalam masyarakat suatu adat tertentu. Hukum adat yang sifatnya tidak tertulis menjadikan hukum adat bersifat dinamis, sehingga mudah menyesuaikan dengan perkembangan zaman (Setiady, 2013: 4).

Hukum waris Minangkabau yang merupakan bagian dari hukum adat mengikuti susunan menurut ibu, maka ahli waris menurut hukum adat Minangkabau dihitung dari garis keturunan ibu (Syarifuddin, 1984: 122). Hukum waris menurut hukum adat Minangkabau senantiasa merupakan masalah yang aktual. Hal itu disebabkan karena kekhasan dan keunikannya bila dibandingkan dengan sistem hukum adat waris dari daerah-daerah lain. Seperti telah dikemukakan, bahwa sistem kekeluargaan di Minangkabau menurut sistem dengan menarik 
garis keturunan dari pihak ibu atau disebut juga dengan sistem matrilineal. (Setiady, 2013:286). Dengan sistem ini, maka semua anak-anak hanya dapat menjadi ahli waris dari ibunya, baik untuk harta pusaka tinggi yaitu harta yang turun-temurun dari beberapa generasi, maupun harta pusaka rendah yang turun dari satu generasi.

Hukum waris adat dengan sistem kekeluargaan matrilineal ini menentukan bahwa anakanak hanya dapat menjadi ahli waris dari ibu, baik dari harta pencarian maupun harta bawaan. Oleh karenanya, kaum dalam masyarakat Minang merupakan persekutuan hukum adat yang mempunyai daerah tertentu yang dinamakan dengan tanah ulayat. Kaum beserta anggotanya diwakili keluar oleh seorang mamak kepala waris. Anggota kaum yang menjadi mamak kepala waris biasanya adalah saudara laki-laki yang tertua dari ibu. Akan tetapi kekuasaan tertinggi di dalam kaum terletak pada rapat kaum, bukan pada mamak kepala waris.

Bushar (1991: 39) dan Hadikusuma (1977: 67) merumuskan hukum adat waris adalah peraturan-peraturan hukum yang bersangkutan dengan proses yang sangat mengesankan serta yang akan selalu berjalan tentang penerusan dan pengoperan kekayaan materiil dan immaterial dari suatu generasi kepada generasi berikutnya. Syarat beralihnya harta orang yang meninggal dunia kepada orang yang masih hidup adalah adanya hubungan kekerabatan di antara keduanya, hubungan kekerabatan ini muncul akibat dari adanya hubungan darah atau perkawinan. Seorang anak yang lahir akan secara alamiah memiliki hubungan kekerabatan dengan ibunya dan saudara-saudara lain yang dilahirkan oleh ibunya, dengan begitu terbentuklah kekerabatan menurut garis ibu.

Dengan demikian, kedudukan laki-laki di Minangkabau memang unik, terutama di dalam masyarakat tradisionalnya. Keunikan ini berakar dari kultur matrialineal yang hingga kini masih dianut oleh masyarakat Minangkabau. Salah satu keunikan itu adalah laki-laki tidak memiliki hak warisan atas pusaka turunan. Yang berhak menerima warisan pusaka dari orangtuanya adalah perempuan. Selain dari itu, laki-laki Minang juga tidak menurunkan suku (marga)-nya kepada anaknya sendiri, melainkan kepada anak saudara perempuannya atau kemenakan. Jika seorang laki-laki tinggal/menetap di rumah orangtuanya setelah berkeluarga dan menggarap sawah ladang orang tuanya sendiri, itu bukan berarti ia dapat menurunkan warisan itu kepada anak-anaknya kalau ia meninggal nanti, sekalipun ia tidak memiliki saudara perempuan seayah-seibu, masih ada saudara perempuan sepupu untuk 
ljtihad, Jurnal Wacana Hukum Islam dan Kemanusiaan, Volume 17, No. 1, Juni 2017: 85-112

menerima warisan itu. Malahan tinggal dan menggarap sawah ladang di rumah dan di tanah orangtua sendiri, kadang dianggap kurang baik.

Lain halnya di masyarakat Mandailing yang menganut sistem kekeluargaan patrilineal yaitu garis keturunan ditarik dari ayah. Hal ini terlihat dari marga yang dipakai oleh orang Mandailing yang turun dari marga ayahnya. Melihat hal ini secara otomatis bahwa kedudukan kaum ayah atau laki-laki dalam masyarakat adat dapat dikatakan lebih tinggi dari kaum wanita. Dalam pembagian warisan, yang mendapatkan warisan adalah anak laki-laki sedangkan anak perempuan mendapatkan bagian dari orang tua suaminya atau dengan kata lain pihak perempuan mendapatkan warisan dengan cara hibah. Pembagian harta warisan untuk anak laki-laki juga tidak sembarangan, karena pembagian warisan tersebut ada kekhususan yaitu anak laki-laki yang paling kecil atau dalam bahasa bataknya disebut Siapudan, dan ia mendapatkan warisan yang khusus. Patrilineal adalah suatu adat masyarakat yang mengatur alur keturunan berasal dari pihak ayah. Ketika terjadi masalah maka yang bertanggungjawab adalah pihak laki-laki. Sistem kekeluargaan ini dianut oleh suku Mandailing.

Kata patrilineal seringkali disamakan dengan patriarkhat atau patriarkhi, meskipun pada dasarnya artinya berbeda. Patrilineal berasal dari dua kata, yaitu pater yang berarti “ayah", dan linea yang berarti "garis". Jadi, "patrilineal” berarti mengikuti "garis keturunan yang ditarik dari pihak ayah". Sementara patriarkhat berasal dari dua kata yang lain, yaitu pater yang berarti "ayah" dan archein yang berarti "memerintah". Jadi, "patriarkhi" berarti "kekuasaan berada di tangan ayah atau pihak laki-laki”. Dari pengertian tersebut jelas terlihat perbedaan makna dari kedua kata tersebut. Patrilineal mengarah ke garis keturunan dan patriarkhat lebih menjurus ke arah kekuasaan, meski kedua hal tersebut sama-sama memiliki kaitan dengan pihak laki-laki.

Hak anak tiri ataupun anak angkat dapat disamakan dengan hak anak kandung, karena sebelum seorang anak diadopsi atau diangkat, harus melewati proses adat tertentu. Yang bertujuan bahwa orang tersebut sudah sah secara adat menjadi marga dari orang yang mengangkatnya. Tetapi memang ada beberapa jenis harta yang tidak dapat diwariskan kepada anak tiri dan anak angkat yaitu pusaka turun-temurun keluarga, karena yang berhak memperoleh pusaka turun-temurun keluarga adalah keturunan asli dari orang yang mewariskan. 
Dalam adat Batak, peraturan adat-istiadatnya terkesan lebih ketat, itu ditunjukkan dalam pewarisan, anak perempuan tidak mendapatkan apapun. Yang paling banyak dalam mendapat warisan adalah anak bungsu atau disebut siapudan. Yaitu berupa tanah pusaka, rumah induk atau rumah peninggalan orang tua dan harta yang lainnya dibagi rata oleh semua anak lakilakinya. Anak siapudan tidak boleh pergi meninggalkan kampung halamannya, karena anak siapudan tersebut sudah dianggap sebagai penerus ayahnya. Misalnya jika ayahnya Raja Huta atau kepala kampung, maka turun kepada anak bungsunya.

Menurut sistem patrilineal ini keturunan diambil dari garis bapak, yang merupakan pancaran dari bapak asal dan menjadi penentu dalam keturunan anak cucu. Dalam hal ini perempuan tidak menjadi hubungan darah yang menghubungkan keluarga. Wanita yang kawin dengan laki-laki ikut dengan suami dan anaknya menjadi keluarga ayahnya. Sistem pertalian seperti ini terjadi di Nias, Gayo, Batak dan sebagian di Lampung, Bengkulu, Maluku dan Timor. Dalam hukum waris, persekutuan ini lebih mementingkan keturunan anak laki-laki daripada anak perempuan.

Fenomena menarik ditemukan pada komunitas multi etnis di daerah perbatasan Minangkabau. Dengan adanya migrasi etnis Mandailing ke daerah ini, dengan sendirinya mereka membutuhkan lahan tempat tinggal dan pencaharian yang diperoleh dari etnis asli Minangkabau, baik dengan cara pegang gadai, sewa-kontrak, dan bahkan diperoleh dalam transaksi jual beli. Maka dengan sendirinya di daerah multi ini terjadi perubahan sistem peralihan kepemilikan harta.

Penelitian ini sesungguhnya ingin memahami lebih dalam tentang gejala sosial keagamaan dan budaya masyarakat adat lokal di perbatasan Minangkabau khususnya dalam pelaksanaan hukum kewarisan. Interaksi antara penduduk asli Minangkabau dan pendatang yang berasal dari daerah utara telah memunculkan konstruksi sejarah, melahirkan tradisi agama dan kebudayaan yang berbeda dengan daerah asal (darek) yang mayoritas beretnis Minangkabau.

\section{Penelitian yang Relevan}

Studi tentang hukum kewarisan Islam sudah banyak dilakukan orang, baik dalam bentuk penelitian hukum normatif maupun dalam bentuk penelitian sosiologi dalam berbagai bentuk pendekatannya. Karya dalam bentuk hukum kewarisan sosiologis, misalnya karya Amir 
ljtihad, Jurnal Wacana Hukum Islam dan Kemanusiaan, Volume 17, No. 1, Juni 2017: 85-112

Syarifuddin dengan judul, "Pelaksanaan Hukum Kewarisan Islam dalam Lingkungan Adat Minangkabau". Penelitian ini merupakan disertasi yang antara lain menyatakan bahwa penundukan adat kepada Islam dalam tahap ini tidaklah berarti bahwa adat dengan sendirinya telah menyesuaikan diri dengan sepenuhnya dengan Islam, karena penyesuaian ini memerlukan waktu yang cukup panjang dan tidak terjadi tanpa benturan. Praktek-praktek kehidupan adat kelihatannya masih terus berjalan, terutama yang menyangkut dalam masalah warisan, karena harta pencarian suami masih dibawa menurut ketentuan adat oleh kaumnya, bukan oleh anak-anaknya (Syarifuddin, 1984: 20).

Zikri Darussamin dalam disertasi dengan judul: Interaksi Hukum Islam dan Adat (Studi Pelaksanaan Kewarisan Masyarakat Melayu di Daerah Siak). Interaksi antara hukum kewarisan Islam dengan kewarisan hukum adat dipengaruhi oleh beberapa faktor, yaitu: adat, kesamaan sistem kekerabatan, dan fleksibelitas hukum kewarisan Islam. Di antara faktor-faktor tersebut adat merupakan faktor utama yang menyebabkan dominannya hukum kewarisan Islam. Meskipun pelaksanaan hukum kewarisan di daerah Melayu Siak didominasi oleh hukum kewarisan Islam, namun untuk masa yang akan datang eksistensi hukum kewarisan Islam sangat mungkin mengalami perubahan (Darusamin, 2012: 200).

Azhari Akmal Tarigan, dalam disertasinya dengan judul "Pelaksanaan Hukum Waris Pada Masyarakat Karo Muslim Di Kabupaten Karo", memaparkan, dalam masyarakat Karo untuk menyelesaikan sengketa warisnya menganut hukum waris adat yang dinamis dan 'bergerak' terutama kesadaran akan hak-hak anak perempuan dan hak janda untuk memperoleh dan memanfaatkan harta waris. Dalam memberi akses harta waris kepada anak perempuan, pewaris menempuh strategi-strategi tertentu melalui wasiat, hibah (pemere) dan investasi pendidikan. Lebih lanjut, ia menjelaskan bahwa hukum waris adat Karo bergerak sesungguhnya lebih disebabkan dinamika yang muncul dari dalam masyarakat Karo itu sendiri, seperti kesadaran akan hak-hak perempuan dan tentu saja pengaruh dari ajaran Islam itu sendiri (Tarigan, 2010: 32).

Tarigan menyebutkan, fenomena ini menunjukkan hukum waris adat Karo dalam hal kewarisan anak perempuan sedang bergerak ke individualbilateral. Sedangkan janda selama belum keluar dari lingkungan keluarga suaminya, ia berhak mengelola harta peninggalan suaminya sampai akhir hayatnya. Dalam hal ahli waris berbeda agama, masyarakat Karo 
muslim tetap menggunakan hukum adat kendati ajaran fikih melarangnya. Bagi masyarakat Karo muslim, perbedaan agama tidak menyebabkan seseorang terhalang untuk memperoleh harta waris.

Hasil penelitiannya menunjukkan bahwa masyarakat Karo muslim tetap menggunakan hukum waris adat Karo dalam menyelesaikan sengketa dan pembagian harta waris. "Mereka memilih runggun sebagai lembaga yang menyelesaikan sengketa yang mereka hadapi. Keberadaan sangkep sitelu seperti kalimbubu, anak beru dan senina masih sangat efektif untuk menyelesaikan sengketa yang terjadi," sebutnya. Dia menyebutkan, Pengadilan Agama menjadi pilihan berikutnya jika runggun dipandang gagal menyelesaikannya. "Kendati masyarakat Karo muslim masih menggunakan hukum waris adat, namun bukanlah hukum waris adat yang statis, konsisten dan koheren. Hukum waris adat yang mereka praktikkan saat ini adalah hukum waris yang dinamis dan 'bergerak'.

\section{Sistem perkawinan dan kewarisan dalam adat Minangkabau}

Perkawinan dalam tradisi Minangkabau terjadi secara eksogami dengan sistem menetap uksorilokal yaitu suami tinggal di rumah keluarga istri. Mereka hidup dalam suasana keluarga luas (extended family) (Benda Backmann: 2006: 122). Suami istri atau salah satu pihak dari yang menikah itu tidak lebur ke dalam kaum kerabat pasangannya. Menurut struktur adat setiap orang adalah warga kaum dan suku mereka masing-masing yang tidak dapat dialihkan. Jadi setiap orang tetap menjadi warga kaumnya masing-masing, meskipun telah diikat perkawinan. Tradisi eksogami ini pernah dikritik oleh Haji Rasul sebagai perbuatan maksiat di rumah tangga. Seorang suami yang tinggal dalam keluarga besar di rumah gadang bercampur dengan saudara perempuan istri sebagai muhrim yang boleh dikawini kalau sang istri meninggal. Inilah menurut Haji Rasul perbuatan haram yang sudah menjadi kebiasaan di Minangkabau (Hadler, 2010: 20).

Pada prinsipnya, suami atau ayah bukanlah anggota dari keturunan anak-anaknya, ayah diperlakukan sebagai tamu dalam keluarga yang dapat memberikan keturunan. Dia dinamai sumando atau urang sumando. Tempat yang sah baginya adalah dalam keturunan ibunya. Buya Hamka mempunyai catatan pribadi dalam menjelaskan peran ayah dalam sistem adat Minangkabau. Meskipun selama masa kanak-kanaknya, ia pernah tinggal bersama ibunya. 
ljtihad, Jurnal Wacana Hukum Islam dan Kemanusiaan, Volume 17, No. 1, Juni 2017: 85-112

Tapi ayahnya seorang sarjana muslim terkenal Haji Abdul Karim Amrullah, berkeinginan agar Hamka kecil menjadi ulama terkenal. Keinginan yang diutarakan saat Hamka lahir ini mempunyai konsekuensi supaya ia diasuh dan tinggal bersama ayahnya. Hal ini tentu sesuatu yang tidak biasa dalam tradisi adat Minangkabau karena anak-anak sejak kecil dianggap sebagai anggota keluarga dari keturunan ibunya (Hamka,1966: 34) Bahkan pengalaman serupa terdapat pada Muhammad Radjab, seorang penulis Minangkabau, mengalami pola hidup yang sama dengan Hamka, ketika masih kecil tinggal bersama ayahnya yang juga menjadi guru agama terkemuka (Radjab, 1969: 21).

Secara tradisional, setidak-tidaknya tanggung jawabnya berada di keluarga ibunya. Anak yang lahir dari perkawinan menjadi anggota kaum sang istri, sehingga ayah tidak perlu bertanggung jawab terhadap keluarga anaknya. Perkawinan eksogami meletakkan para istri pada status yang sama dengan suaminya. Sistem matrilineal dan pola hidup komunal menyebabkan mereka tidak tergantung pada suami. Istri pantang mengeluh kepada suaminya, sehingga para suami tidak mempunyai beban pikiran yang berat di rumah tangganya. Ayah adalah wali (mamak) dari garis keturunannya dan pelindung atas harta garis keturunannya, sekalipun dia harus menahan diri dari hasil tanah kaum tersebut, dan dia tidak dapat menuntut bahagian tanah untuk dirinya. Tidak pula diberi tempat di rumah tersebut, karena bilik (kamar) hanya diperuntukkan bagi anggota keluarga perempuan (Radjab, 1969: 21).

Hanya saja, laporan antropolog terdahulu lebih menekankan peran dan dominasi yang berlebihan pada penghulu dan tidak menggambarkan otoritas kaum perempuan tua. Para pembuat kebijakan kolonial juga sering beranggapan bahwa kepala keluarga Minangkabau selalu laki-laki. Namun, Korn sebagaimana dikutip Renske Biezeveld menunjukkan bahwa perempuan-perempuan tua sering kali bertindak sebagai kepala keluarga. Hal ini terjadi bukan karena tidak adanya laki-laki dalam keluarga akibat perantauan laki-laki, perceraian, atau kematian suami. Dalam aturan tradisional Minangkabau penjaga harta warisan (pusako) umumnya dipegang oleh perempuan tertua di suatu kaum. Hal ini sejalan dengan Willinck yang juga dikutip Biezeveld menyatakan bahwa perempuan tertua dalam sebuah puak sebenarnya berkedudukan lebih tinggi dari pada mamak (paman dari pihak ibu) (Biezeveld, 2010: 227).

Dengan demikian, Adat Minangkabau memiliki pengertian tersendiri tentang sistem kewarisan. Beberapa asas pokok dalam hukum kewarisan adat Minangkabau adalah sebagai 
berikut: a. Asas Unilateral. Asas unilateral adalah hak kewarisan yang hanya berlaku dalam satu garis kekerabatan, dan satu garis kekerabatan di sini adalah garis kekerabatan ibu. Harta pusaka dari atas diterima dari nenek moyang hanya melalui garis ibu ke bawah diteruskan kepada anak cucu melalui anak perempuan, sama sekali tidak ada yang melalui garis laki-laki baik ke atas maupun ke bawah. b. Asas Kolektif. Asas ini berarti bahwa yang berhak atas harta pusaka bukanlah orang perorangan, tetapi suatu kelompok secara bersama-sama. Berdasarkan asas ini maka harta tidak dibagi-bagi dan disampaikan kepada kelompok penerimanya dalam bentuk kesatuan yang tidak terbagi. Dalam bentuk harta pusaka tinggi adalah wajar bila diteruskan secara kolektif, karena pada waktu penerimaannya juga secara kolektif. Harta pusaka rendah masih dapat dikenal oleh pemiliknya yang oleh si pemilik diperoleh berdasarkan pencariannya. Harta dalam bentuk inipun diterima secara kolektif oleh generasi berikutnya (Syarifuddin, 1984: 231).

Sedangkan hubungan antara pewaris dengan penerima warisan dapat dibedakan atas dua bagian, yaitu:

\section{Waris Nasab atau Waris Pangkat}

Waris nasab maksudnya antara si pewaris dengan yang menerima warisan terdapat pertalian darah berdasarkan keturunan ibu. Harta pusaka tinggi yang disebut pusako secara turun temurun yang berhak mewarisi adalah anggota kaum itu sendiri dari pihak perempuan. Hal ini sesuai dengan garis keturunan matrilineal. Mengenai pewarisan gelar pusaka yang disebut sako sepanjang adat tetap berlaku dari mamak kepada kemenakan laki-laki. Dalam kewarisan sako ini dikatakan: Ramo-ramo si kumbang jati, katik endah pulang bakudo, patah tumbuah bilang baganti, pusako lamo baitu pulo (Anwar, 1997: 92). Waris nasab yang berkaitan dengan sako dapat pula dibagi atas dua bagian yaitu: $a$. Warih Nan Saluruih (waris yang selurus). Dalam adat dikatakan saluruib ka ateh, saluruih ka bawah nan salingkuang cupak adat, nan sapayuang sapatagak. Artinya keturunan setali darah sehingga delapan kali keturunan atau disebut juga empat ke atas, empat ke bawah menurut ranji yang benar. Seperti kaum yang sudah berkembang yang pada mulanya dari tiga orang nenek. Turunan laki-laki dari ketiga nenek ini sama-sama berhak untuk memakai pusaka kaum yang dimiliki. Gelar pusaka kaum tadi tidak boleh pindah atau digantikan kepada lingkungan kaum lainnya, selain dari kaum keluarga 
ljtihad, Jurnal Wacana Hukum Islam dan Kemanusiaan, Volume 17, No. 1, Juni 2017: 85-112

ketiga nenek yang sekaum ini dalam adat dikatakan "suku dapek disakoi, pusako dipusakoi", gelar pusaka dapat digantikan dan harta pusaka boleh dipusakai. b. Warih Nan Kabuliah. Dalam adat dikatakan "jauah dapek ditunjuakean, dakek dapek dikakokkan, satitiak bapantang bilang, sabarih bapantang lupo", (jauh dapat ditunjukkan, dekat dapat dipegang, setitik tidak hilang, sebaris tidak lupa). Maksudnya belahan yang asli dari sebuah kaum yang sampai sekarang masih dapat dicari asal usulnya. Seperti anggota kaum pindah ke nagari yang berdekatan dan menetap sebagai penduduk di nagari tersebut karena sudah berkembang, maka mereka ingin untuk mengangkat gelar kebesaran kaum. Pada kaum yang ditinggalkannya mempunyai gelar pusaka Datuak Marajo. Di tempat baru belahan kaum yang pindah ini dapat pula mengangkat gelar Datuak Marajo. Sepanjang adat yang dapat memakai gelar pusaka kaum adalah orang yang ada pertalian darah. Kemenakan bertali adat, dan bertali budi tidak dibenarkan memakai gelar kebesaran kaum karena tidak bertali darah. Adat mengatakan "sako tatap pusako baranjak" (sako tetap, pusaka beranjak), artinya gelar pusaka tidak dapat berpindah dari lingkungan keturunan asli kecuali harta pusaka. Gelar pusaka kaum tidak dibenarkan dipakai oleh orang di luar kaum, dengan alasan bila terjadi akan membawa dampak negatif dari kaum tersebut. Adat mengatakan di mano batang taguliang, disinan tindawan tumbuah, di mano tanah dipijak, disinan langit dijunjuang (Anwar: 1997:58). Ketentuan adat ini mempunyai pengertian bila gelar pusaka itu dipakai oleh seseorang, maka menurut adat orang yang memakai gelar pusaka ini akan diikuti kebesarannya oleh harta pusaka yang ada pada kaum itu. Dengan arti kata semua harta pusaka tinggi yang ada pada kaum itu berada di tangannya, dan kaum tadi akan bermamak kepada penghulu baru ini yang tidak seketurunan dengannya.

\section{Warih Sabab atau Warih Badan}

Waris "sebab" maksudnya hubungan antara pewaris dengan penerima warisan tidak karena hubungan darah, tetapi karena sebab. Di dalam adat dikatakan "basiang dinan tumbuah, menimbang dinan ado". Waris sebab ini seperti karena bertali adat, bertali buat, dan bertali budi. Waris sebab hanya menyangkut harta pusaka dan dapat dibedakan atas tiga bagian, yaitu: Pertama, Warih Batali Adat (waris bertali adat). Waris bertali adat seperti hubungan sesuku yang punah, (keturunan untuk melanjutkan kaum tidak ada lagi menurut garis keibuan), akhirnya harta 
pusaka dari kaum yang punah tersebut dapat jatuh kepada kaum yang sesuku dengannya di kampung tersebut; Kedua, Warih Batali Buek (waris bertali buat). Buek artinya peraturan atau undang-undang. Waris bertali buek maksudnya waris berdasarkan peraturan yang dapat dibenarkan oleh adat. Warih batali buek ini berlaku "manitiak mako ditampuang, maleleh mako dipalik, sasuai mako takanak, saukua mako manjadi'. Seperti seorang bapak yang sudah punah keluarganya maka atas mufakat dengan waris bertali adat, si bapak dapat memberikan harta pusaka kepada anaknya, tetapi tidak gelar pusaka dari kaum; Ketiga, Warih Batali Budi (waris bertali budi). Menjadi waris karena kebaikan budi dari kaum yang didatanginya karena rasa kasihan dan tingkah lakunya yang baik sehingga sudah dianggap anak kemenakan, ia diberi hak atas harta pusaka namun tergantung pada kata mufakat dalam kaum tersebut.

Waris menurut adat Minangkabau tidak ada istilah "putus" karena dalam warisan ini adat menggariskan "adanya" waris yang bertali adat, bertali buek, bertali budi dan hal ini bila ada kesepakatan kaum. Bila kaum itu punah maka warisan jatuh kepada waris yang bertalian dengan suku dan bila yang sesuku tidak ada pula harta pusaka kaum yang punah itu jatuh pada nagari, ninik mamak nagarilah yang menentukan. Menurut Iskandar Kemal, bila tidak ada perut yang terdekat, anggota waris yang terakhir dapat menentukan sendiri waris yang terdekat dari orang-orang yang bertali adat untuk melanjutkan hak-hak dari perut itu, sesudah punah sama sekali, baru ditentukan oleh kerapatan adat nagari.

Di samping pembagian di atas terdapat pula kategori lain menurut hukum adat Minangkabau di antaranya; (1), Waris Bertali Darab yaitu ahli waris kandung atau ahli waris sedarah yang terdiri dari ahli waris satampok (waris setampuk), waris sajangka (waris sejengkal), dan waris saheto (waris sehasta). Masing-masing ahli waris yang termasuk waris bertali darah ini mewaris secara bergiliran, artinya selama waris bertali darah setampuk masih ada, maka waris bertali darah sejengkal belum berhak mawaris. Demikian pula waris seterusnya selama waris sejengkal masih ada, maka waris sehasta belum berhak mewaris; (2) Waris Bertali Adat yaitu waris yang sesame ibu asalnya yang berhak memperoleh hak warisnya bila tidak ada sama sekali waris bertali darah. Setiap nagari di Minangkabau mempunyai nama dan pengertian tersendiri untuk waris bertali adat sehingga waris bertali adat ini dibedakan sebagai berikut; a) Waris menurut caranya menjadi waris: waris batali ameh, waris batali suto, waris batali budi, waris tambilang basi, waris tambilang perak; b) Menurut jauh-dekatnya terdiri 
ljtihad, Jurnal Wacana Hukum Islam dan Kemanusiaan, Volume 17, No. 1, Juni 2017: 85-112

dari: waris dibawah daguek, waris didado, waris di bawah pusat, waris di bawah lutut; c) Menurut datangnya, yaitu: waris orang dating, waris air tawar, waris mahindu. (Wicaksono, 2011: 10); (3) Waris Bertali Budi yaitu waris dari orang lain yang sering dating berkunjung di bawah lindungan satu penghulu; (4) Waris di Bawah Lutuik, yaitu waris yang asalnya tidak jelas dan keturunan pembantu (budak) yang menetap sebagai anggota kerabat (Suparman, 1985: 20).

Dari keempat macam ahli waris atau kemenakan tersebut yang sebagai ahli waris adalah kemenakan bertali darag yang sepuluhan ke bawah dan sepuluhan ke atas. Para ahli waris tersebut berhak menghalangi tindakan mamak kepala waris terhadap harta pusaka yang tidak mereka setujui. Sedangkan kemenakan lainnya, yang bertali adat, bertali budi, dan dibawah lutuik bukan ahli waris dari satu gadang (sabuah paruik) atau dari satu kesatuan kerabat yang disebut "kaum" (Wicaksono, 2011: 25). Sedangkan hak mewaris dari masingmasing ahli waris yang disebutkan diatas satu sama lain berbeda-beda bergantung pada jenis harta peninggalan yang akan ia warisi dan hak mewarisnya diatur menurut urutan prioritasnya. Hal tersebut akan dapat terlihat dalam paparan di bawah ini.

Dengan demikian, hukum waris adat dengan system kekeluargaan matrilineal ini menentukan bahwa anak-anak hanya dapat menjadi ahli waris dari ibu, baik harta pencaharian maupun harta bawaan (harta pusaka), oleh karenanya, sebagaimana diketahui, bahwa "kaum" dalam masyarakat Minangkabau merupakan persekutuan hukum adat yang mempunyai daerah tertentu yang dinamakan "tanah ulayat". Kaum serta anggota kaum diwakili keluar oleh seorang "mamak kepala waris". Anggota kaum yang menjadi mamak kepala waris lazimnya adalah saudara laki-laki yang tertua dari ibu, mamak kepala waris harus cerdas dan pintar. Akan tetapi kekuasaan tertinggi di dalam kaum terletak pada rapat kaum, bukan pada mamak kepala waris. Anggota kaum terdiri dari kemenakan dan kemenakan ini adalah ahli waris.

\section{Sistem perkawinan dan kewarisan dalam adat Mandailing}

Masyarakat Mandailing termasuk dalam sistem kekeluargaan patrilineal, sistem Patrilineal yang dianut dan dikembangkan masyarakat Mandailing dapat dilihat dari kebudayaan yang dianut dan di implementasikan dalam masyrakat tersebut sampai saat ini, antara lain adalah 
bahwa hanya anak laki-laki saja yang dapat melanjutkan garis keturunan ayahnya atau lebih akrabnya hanya anak lakilaki yang dapat meneruskan marga dari ayahnya dan hanya anak laki-laki jugalah yang menjadi ahli waris.

Perkawinan berdasarkan adat berarti berlangsungnya secara perkawinan itu tidak bertentangan dengan norma-norma adat (perkawinan secara wajar. Adapun perkawinan yang wajar itu tentu berangkatnya pengantin wanita dari rumah orang tuanya menuju rumah pengantin laki-laki mendapatkan persetujuan dari orang tua kedua belah pihak.

Adapun cara-cara sebelum perkawinan dilaksanakan, yaitu; (1) Mangkobar Boru, yaitu perundingan mengenai uang perkawinan dari pihak Mangkobar boru dengan orang kaya di kampung bersama tua moranya, hatobangon, harajaon dan anak boru yang diutus pihak laki-laki; (2) Indahan tungkus pasae robu, yaitu setelah boru melangkahkan kaikinya kerumah namborunya, mufakatlah orang tuanya sehubungan dengan rencana mengantarkan indahan tungkus pase robu. Selama anak gadis mereka melangkah kaki mereka masih marrobu (tidak boleh saling mengunjungi). Antara mora dengan anak boru tidak boleh saling mengunjungi selama indahan toppu belum diantar pihak mora kepada borunya. Menurut kebiasaan kalau terjadi kunjungan-mengunjungi antara keduannya sebelum indahan toppu robu selesai, maka kata orang-orang tua akan muncul kesusahan; (3) Paulak indahan toppu robu, yaitu sebagai balasan indahan toppo robu yang diantarkan pihak mora ke rumah pihak anak borunya. Orang yang berangkat kerumah mora (malungun) terdiri dari boru (pengantin perempuan), bayo (pengantin laki-laki), amang boru, namborunya, kahanggi, anak borunya dan beberapa orang gadis; (4) Mebat lungun, yaitu setelah beberapa bulan gadis melangkahkan kakinya memasuki jenjang rumah tangga, maka tibalah waktunya mereka mengunjungi rumah orang tuanya (pihak mora) yang ada dalam adat Mandailing disebut mebat. Mebat lungun dilakukan sekaligus saat paulak indahan toppu robu, biasanya dilaksanakan pada hari yang sama. Selanjutnya barang-barang yang mau diberikan dikumpulkan di hadapan mereka. Kain dan pakaian pemberian kaum family dimasukan ke dalam sumpit atau hadangan situdu na marihot (Ritonga, 2002: 53).

Dalam perkawinan adat Mandailing pun tidaklah diizinkan melakukan perkawinan sesama marga Adapun dalam hukum waris adat Mandailing akan dijelaskan hukum waris adat meliputi aturan-aturan dan keputusan-keputusan hukum yang bertalian dengan proses 
ljtihad, Jurnal Wacana Hukum Islam dan Kemanusiaan, Volume 17, No. 1, Juni 2017: 85-112

penerusan atau pengoperan dan peralihan atau perpindahan harta kekayaan materill dan non-materill dari generasi kegenerasi.

Asas ahli waris utama dan pertama dari Batak Mandailing bahwasanya seperti masyarakat batak lainnya yang menganut paterineal hanya benar terhadap anak laki-laki (meskipun harta benda telah dibawakan kepada anak perempuan tidak boleh diabaikan). Dalam pewarisan dalam suku adat Mandailing bahwa hukum waris yang dipakai mencangkup 3 (tiga) yang diutamakan dalam adat Mandailing, yaitu; (1) Memakai hukum adat sebagai tombak pertama dalam menentukan waris; (2) Memakai hukum Islam, sebab dalam suku Mandailing sudah memeluk agama Islam, maka mereka memakai hukum Islam dalam pewarisan; (3) Memakai hukum konvensional/hukum nasional, sebab bila hukum adat dan hukum Islam tidak ingin dipakai maka mereka memakai hukum nasional (Sudiyat, 1978: 20).

Dalam suku Mandailing mengenai waris cepat-lambatnya orang memakai kata sepakat dalam pembagian harta itu tergantung dari faktor ekonomis dan religio-magis. Seperti:Putraputra Mandailing yang ayahnya mencapai sukses didalam hidupnya, ingin secepat mungkin memiliki pembagian di dalam harta pencarian almarhum; dengan pemilikan itu mereka akan turut menikmati sukses yang terkandung di dalam harta tersebut sebagai kekuatan gaib; sebaliknya, lading-ladang warisan kakek leluhur mereka misalnya akan mereka biarkan tetap tak terbagi seumur hidup.

Waris utama pada kekerabatan Paterilineal khususnya suku Mandailing maka dalam hal ini terasakah adanya ketegangan antara tuntutan hak dari kesatuan keluarga dengan tuntutan hak dari kerabat tersebut yang ingin mewarisi harta kepada keluarga.

Dalam pembagian warisan dalam suku mandailing yang memiliki waris di bagi atas 3 (tiga), yaitu; (1) Anak laki-laki tertua; (2) Anak laki-laki termuda; (3) Anak laki-laki sulung dan bungsu (Sudiyat, 1978: 70).

Hambatan dalam waris adat Mandailing adalah anak tidak mewarisi sari salah seorang di antara orang tertuanya yang instusional tetap tinggal dalam kerabatnya, sedangkan anakanak tidak masuk di dalamnya. Dan suatu hambatan lain bagi anak di dalam terlaksana bersegi satu untuk mewarisi dari kedua orangtua, ialah bentuk perkawinan yang berakibat bahwa anak yang kawin dibebaskan dari panguyuban hidup kekerabatan. Contoh dimana anak perempuan dengan perkawinan keluar dari kerabat ayahnya, sehingga ia tidak dapat 
menuntut hak mawaris tanpa wasiat.

Dan dalam Adat Mandailing yang sudah mengalami perubahan dikarenakan dalam adat tersebut sudah berbaur dengan agama. Sehingga dalam adat Mandailing hukum yang menetapkan dalam waris adalah memakai hukum Islam. Walaupun lebih banyak laki-laki yang mendapat waris seperti halnya hukum adat, namun dari pihak perempuan pun mendapat bagian dalam waris yang telah ditentukan dalam hukum Islam. Itulah sebabnya hukum adat mulai banyak dilupakan yang menyebabkan pergantian dalam adat Mandailing.

Dengan demikian, sistem kekeluargaan patrilineal yang dianut oleh masyarakat mandailing menjelaskan dimana hanya anak laki-laki yang dapat meneruskan garis keturunan dari orang tuanya dimana dalam pembagian harta warisan anak laki-laki lebih diutamakan dari pada anak perempuan. Hal ini menunjukkan tidak adanya persamaan kedudukan antara laki-laki dan perempuan dalam hal mewarisi dari kedua orang tuanya. Seiring dengan berkembangnya zaman, pada umumnya masyarakat Mandailing yang beragama Islam dan mengikutu ajaran serta tata cara Islam, salah satunya dalam pembagian harta warisan. Dalam hukum kewarisan Islam, dimana dijelaskan bahwa menerima harta warisan tidak hanya anak laki-laki saja, tetapi perempuan juga memiliki hak atas harta warisan orang tuanya.

Menurut penelitian Farida Hanum, pelaksaaan sistem hukum kewarisan mempunyai perbedaan yang prinsipil misalnya antara hukum waris Islam dan hukum waris adat, berbeda dalam hal sistem kekeluargaan, pengertian kewarisan, harta peninggalan ahli waris, bagian ahli waris, lembaga penggantian ahli waris dan sistem hibah. Dalam prakteknya sering dijumpai pelaksanaan pembagian warisan ditunda-tunda, sedangkan Hukum Waris Islam tidak mengenal masa tunggu untuk melaksanakan pembagian warisan sedangkan pada prakteknya harta warisan dibiarkan tetap utuh dalam jangka waktu yang lama bahkan ada yang sampai turun kegenerasi berikutnya. Bahkan terkadang hukum waris Islam itu tercampur dengan keberadaan hukum waris adat tak terkecuali pada masyarakat hukum adat Mandiling Godang. Menurut penelitiannya, pelaksanaan hukum waris pada masyarakat Mandailing Godang belum sepenuhnya berdasarkan hukum waris Islam. Dimana dalam menentukan objek harta warisan pada umumya masih membedakan harta pusaka dan harta pencaharian sedangkan menurut hukum waris Islam objek harta warisan adalah 12 (setengah) dari harta pencaharian dan harta pusaka. Pada umumnya bagian para ahli waris masih berdasarkan hukum adat. 
ljtihad, Jurnal Wacana Hukum Islam dan Kemanusiaan, Volume 17, No. 1, Juni 2017: 85-112

Kalaupun ada bagian ahli waris berdasarkan hukum waris Islam, ayah dan Ibu belum termasuk ahli waris utama. Cara pembagian harta warisan pada umumnya langsung melaksanakan musyawarah. Pada hal seharusnya ditentukan lebih dahulu bagian masing-masing ahli waris sehingga masing-masing memahami bagiannya. Setelah masing-masing memahami bagiannya baru dilaksanakan tsaluh. Hambatan pelaksanaan hukum waris Islam ada beberapa faktor; pertama faktor adat yaitu masih berpegang pada hukum warisan adat dan kedua kurangnya sosialiasi oleh pemuka adat tentang hukum warisan Islam di tengah-tengah masyarakat. Sedangkan cara penyelesaian jika terjadi sengketa yaitu dengan cara pertama; cara musyawarah adat, tetapi tidak bersifat final dan kedua ke Pengadilan Agama (Hanum, 2007: 1)

\section{Asal usul komunitas Rao Pasaman}

Menurut Majalah Sumbago -sebuah media yang mengupas tentang adat dan kebudayaan Minangkabau, dikatakan bahwa Rao Mapat Tunggul termasuk bagian dari kerajaan Pagaruyung. Beberapa pendapat tokoh masyarakat, dapat dikemukakan sebagai berikut: Pertama, versi yang dikemukakan Ramli Hasan ada dua orang berasal dari Balai Janggo Pagaruyung bernama Tumbarido dan Tum Kayo, mencari tanah yang dapat digarap di daerah utara Pagaruyung. Setelah didapat di daerah Pasaman, Tum Barido dan Tum Kayo membagi dua daerah ini. Tumbarido dan pengikut-pengikutnya menerapkan sistem adat koto Piliang. Sedangkan Tum Kayo dan pengikutnya menerapkan sistem adat Bodi Chaniago (Hasan, 2009: 3).

Kedua, versi yang diceritakan oleh Djafri Dt. Bandaro Lubuk Siti dari "warih nan dijawek" yang bersumber dari daerah Limapuluh Koto antara lain menyebutkan, asal usul orang Rao secara umum juga orang-orang di Kabupaten Pasaman, adalah lanjutan dari penyebaran 50 kaum yang berasal dari Pariangan Padang Panjang (Padang Panjang Kecamatan Pariangan, Kabupaten Tanah Datar) yang bergerak ke utara mencari tanah subur untuk pertanian. Empat orang dari yang 50 kaum itu berangkat ke arah utara menyusuri sungai. Satu orang tinggal di Ipuh, satu orang di Mungka Koto Tuo dan yang dua orang terus ke Lubuk Layang/Padang Nunang Rao. Dari Lubuk Layang/Padang Nunang, akhirnya yang berdua ini tinggal di Rao Mapat Tunggul dan Rao Mapat Cancang (Hasan, 2009: 4). 
Ketiga, versi yang ditulis oleh Ahmad Dt. Batuq dan A. Dt. Majo Indo dalam Tambo (Adat) Alam Minangkabau tahun 1996. Disebutkan, daerah Rao itu telah lama didirikan oleh orang Rao yang menurut silsilah berasal dari Pagaruyung. Penduduk Talu dan Cubadak berasal dari Rao yang memberikan tanah pertanian bagi mereka. Salah satu tanah pertanian yang diberikan oleh datuk-datuk tadi itu disebut nagari Sontang.

Keempat, versi yang bersumber dari penelitian Muchtar Naim dalam bukunya "merantau". Ia mengemukakan, asli penduduk Rao itu adalah orang Lubuk, yang disebut juga suku Lubu. Suku Lubu ini termasuk di Minangkabau. Kalau benar pendapat Muchtar Naim ini berarti bahwa orang Rao dan orang Minang umumnya adalah suku tertua di Sumatera. Karena penduduk asli pulau Sumatera adalah suku kubu dan suku Lubu, kalau di Malaysia dikenal dengan suku Semang.

Dari versi-versi di atas, semua berpendapat bahwa orang Rao itu Minangkabau asli. Di atas sudah dijelaskan, ke daerah Rao atau Pasaman ini juga termasuk di dalamnya adat Piliang dan Chaniago. Tetapi kedua sistem ikut dipoles oleh adat-adat lain, mungkin karena faktor Pasaman (apalagi Rao) sangat dekat dengan Mandailing dan Riau. Dekatnya antara Rao dan Mandailing sudah dirasakan lebih 100 tahun yang lalu. Orang-orang Rao dan Mandailing sama-sama berangkat dari kampungnya. Tiba di tujuan juga saling berdiam di desa yang berdekatan dengan orang Kampar atau orang Tanah Putih, Tambusai, Riau. (Hasan, 2009: 5).

\section{Karakteristik masyarakat Rao Pasaman}

Kecamatan Rao merupakan sebuah daerah tapal batas, terletak di kabupaten Pasaman, propinsi Sumatera Barat. Daerah ini berbatasan langsung dengan Tapanuli dan Mandailing, Sumatera Utara. Sebelah utara berbatasan dengan Tapanuli Selatan, sebelah timur berbatasan dengan propinsi Riau, sebelah barat berbatasan dengan kecamatan Lubuk Sikaping, sedangkan sebelah selatan berbatasan dengan kecamatan Panti.

Nama Rao berasal dari kata "rawa" karena di daerah ini dulu banyak terdapat rawarawa. Banyaknya rawa di daerah ini, menyebabkan berkembangbiaknya nyamuk. Banyak dan ganasnya nyamuk tersebut sehingga menimbulkan berbagai penyakit diantaranya penyakit cikunguya dan malaria, penyakit yang disebabkan oleh gigitan nyamuk, penyakit ini bisa 
ljtihad, Jurnal Wacana Hukum Islam dan Kemanusiaan, Volume 17, No. 1, Juni 2017: 85-112

mengakibatkan kematian pada penderitanya. Oleh karena itu, mereka pindah ke daerah Semenanjung, dan di sana mereka disebut sebagai "orang rawa" yaitu orang yang berasal dari daerah rawa-rawa (Fatma, 2011: 2).

Di samping pendapat di atas, di daerah ini dahulunya ada pohon yang tumbuh di daerah rawa yang disebut dengan "rao-rao". Buah pohon inilah yang menjadi makanan nenek moyang dahulunya, maka munculah nama "rao". Daerah Rao yang terletak di perbatasan ini mempunyai ciri khas adat dan budaya tersendiri, pertama, adat pantang tanah. Adat pantang tanah dilakukan melalui upacara bojajak. Upacara ini diperuntukkan kepada anak yang berumur sekitar satu tahun, anak tersebut tidak boleh menginjak tanah sebelum melakukan upacara pantang tanah tersebut. Bahan-bahan yang digunakan yaitu minyak makan, kapur sirih, daun sirih, nasi kunyit, bunga tujuh warna dan lain-lain.

Cara-cara melakukan upacara botatah yang pertama, anak yang akan ditatah disiram dengan beras kuning sebanyak tiga kali, ini dimaksudkan untuk melimpahkan rezeki kepada anak. Kedua menatahkan anak di atas bunga sebanyak tiga kali, juga mengajarkan cara berjalan yang baik. Ketiga memandikan anak dengan mengoleskan minyak makan ke seluruh tubuhnya. Keempat, anak dimandikan bersama ibu dan penatahnya. Setelah dua hari pelaksanaan upacara tersebut anak baru boleh menginjak tanah(Fatma, 2011:3).

Kedua, ma andua adalah seni menidurkan anak dengan cara tertentu, seperti diayun dan dinyanyikan dengan nada dan irama khas orang Rao. Dan ketiga adalah rantak kudo yaitu kesenian daerah yang berupa balas pantun, di mana balas pantun ini dinyanyikan dengan irama tertentu. Acara ini biasa dilakukan pada upacara managak gala rajo yaitu upacara pemberian gelar kebangsawanan pada seorang yang telah dipilih oleh masyarakat setempat sebagai pemimpin. Sementara itu, di kalangan muda-mudi juga ada tradisi rontak kudo, tradisi ini biasanya dilakukan pada saat acara perkawinan mulai dari jam 10 malam sampai pagi, mereka berbalas pantun secara bersama-sama.

Karakteristik masyarakat Rao inilah yang membedakannya dengan daerah lain. Namun sangat disayangkan beberapa ciri khas mereka telah memudar bahkan sudah tidak dikenal oleh generasi muda saat ini, seperti rantak kudo dan ma andua. Sedangkan masakan asam kebo juga sudah jarang dijamukan dalam acara adat. 
Rao merupakan daerah rantau yang berada paling ujung Sumatera Barat arah Utara. Kabupaten Pasaman sekarang ini dibagi menjadi dua bagian. Pertama, Pasaman Timur dengan ibu kota kabupaten Lubuk Sikapiang. Kedua, Pasaman Barat dengan ibu kota kabupaten Simpang Ampek. Penduduk Pasaman terdiri dari penduduk lokal dan penduduk imigran. Penduduk lokal adalah masyarakat yang berasal dari Luhak Agam, Tanah Datar dan Lima Puluh Kota yang pindah ke daerah Pasaman hingga Pasaman disebut daerah rantau. Sedangkan penduduk imigran penduduk di luar ras Minang adalah pendatang dari Mandailing dan daerah lainnya yang berasal dari daerah utara.

Sebagai daerah perbatasan, Pasaman menampakkan diri dalam dua sisi, pertama sebagai orang Minangkabau dengan seluruh identitas dan simbol-simbol keminangan. Di sisi lain, Pasaman menampakkan diri sebagai daerah pengaruh dari Tapanuli. Sebagai daerah Minang, Pasaman memiliki pimpinan sama dengan daerah lain di Luhak Nan Tigo yaitu penghulu atau yang disebut dengan urang nan ampek jinih berupa niniak mamak, alim ulama, cadiak pandai, dan bundo kanduang. Di samping itu, pengaruh Mandailing sangat kental terasa dengan kemampuan masyarakat setempat berkomunikasi dengan bahasa Mandailing. Sebagian mereka juga mempunyai marga seperti marga yang ada dalam adat Mandailing seperti Siregar, Nasution, Panjaitan, Dalimunte dan lain sebagainya. Perkiraan Basyral Hamidy Harahap, orang Pasaman yang berasal dari Mandailing di Pantai Barat Pasaman lebih dahulu masuk Islam dibandingkan dengan orang Minangkabau pedalaman. Menurut Basyral, terdahulunya orang Pasaman masuk Islam karena posisi geografi Pasaman yang dekat dengan daerah niaga di Pesisir Pasaman. Selain itu, posisi Pasaman yang berada di pesisir juga dekat dengan daerah pesisir di Pariaman tempat perguruan Syaikh Burhanuddin di Ulakan (Rozi, 2012: 4).

\section{Pelaksanaan perkawinan dan kewarisan di Rao perbatasan Sumatera Barat}

Secara garis besar golongan masyarakat terdiri dari beberapa sifat, yakni golongan masyarakat yang bersifat kebapakan (patrilineal), masyarakat yang bersifat keibuan (matrilineal), dan golongan yang bersifat kebapak ibuan (parental). Kekeluargaan yang bersifat parental merupakan sifat yang paling dominan di seluruh Indonesia. Daerah-daerah yang bersifat parental antara lain, Jawa, Madura, Sumatera Selatan, Aceh, Riau, Kalimantan, Sulawesi, 
ljtihad, Jurnal Wacana Hukum Islam dan Kemanusiaan, Volume 17, No. 1, Juni 2017: 85-112

Ternate dan Lombok. Dalam keadaan ini pada hakekatnya antara suami dan isteri tidak ada perbedaan kedudukannya di dalam keluarga masing-masing. Isteri menjadi anggota keluarga suami dan suami menjadi anggota keluarga isteri. Keadaan ini menimbulkan hal-hal sebagai seperti; (1) Dalam suatu perkawinan seorang suami dan seorang isteri masing-masing memiliki keluarga ganda; (2) Dalam kekeluargaan orang tua keduanya juga memiliki dua keluarga; (3) Dua keluarga yang dimaksud adalah dari keluarga bapak dan keluarga ibunya (Sudarsono, 1991: 234).

Kekeluargaan yang bersifat patrilineal biasanya perkawinan dengan jujuran. Isteri diberi oleh keluarga suami dengan sejumlah uang tunai dan kadang ditambah dengan pemberian lain seperti emas.

Adapun masyarakat yang bersifat matrilineal berarti setelah perkawinan terjadi, maka suami tinggal di rumah isteri atau di lingkungan keluarga isterinya. Suami tidak termasuk ke dalam keluarga isteri, akan tetapi anak-anak keturunannya dianggap milik ibu dan keluarga ibunya. Bapak tidak ikut memiliki, oleh sebab itu ia tidak berkuasa terhadap anak-anaknya dengan menghubungkan dirinya kepada asal silsilahnya menurut jalur penghubung laki-laki. Pada masyarakat patrilineal, seorang laki-laki (ayah/suami) mempunyai keturunan yang terdiri dari semua anak-anaknya baik laki-laki maupun perempuan, sedangkan yang dipandang sebagai cucu hanyalah mereka yang lahir dari anak-anaknya yang laki-laki saja. Anak perempuan dipandang tidak layak untuk menghasilkan keturunan bagi keluarga ayah dari anak perempuan tersebut. Keadaan ini berlangsung terus menerus di dalam masyarakat, seperti masyarakat Mandailing (Sudarsono, 1991: 235).

Ketiga sistem kekeluargaan di atas, baik sistem parental, patrilineal, dan matrilineal samasama berlaku di tengah-tengah masyarakat Rao. Keseluruhan sistem tersebut menghasilkan nama dan keadaan-keadaan tertentu di dalam masyarakat. Selanjutnya khusus di dalam sistem patrilineal dan sistem matrilineal selalu menimbulkan kesatuan-kesatuan kekeluargaan yang di dalam ilmu pengetahuan sering disebut clan. Di tanah Batak kesatuan kekeluargaan yang terbesar dinamakan marga, seperti marga Lubis, Nasution dan sebagainya. Di Minangkabau clan itu ialah suku, seperti suku Sikumbang dan sebagainya.

Berdasarkan sistem keturunan mereka maka orang-orang yang semarga di tanah Batak ialah semua laki-laki dan perempuan yang menarik garis keturunannya secara patrilineal dari 
bapak ke bapak dan seterusnya melalui penghubung laki-laki sampai kepada moyang lakilaki yang menjadi asal pertama, karena jarak waktu yang sudah begitu lama, orang-orang yang seclan itu percaya bahwa mereka berasal dari moyang laki-laki yang pertama itu. Begitu pula orang yang sesuku di Minangkabau adalah orang-orang yang percaya bahwa mereka seasal dan seketurunan, selalu dengan melalui penghubung yang perempuan sampai kepada seorang nenek moyang perempuan, moyang asal bersama dari mereka.

Hidup clan itu dipertahankan oleh mereka dengan jalan bentuk perkawinan yang mereka pergunakan, yaitu di Minangkabau dengan bentuk perkawinan sumendo yang cirinya memiliki dua sifat, pertama exogam dan kedua matrilokal. Exogam ialah larangan untuk mengawini anggota seclan. Perempuan suku Sikumbang tidak boleh kawin dengan laki-laki suku Sikumbang. Sedangkan matrilokal ialah perempuan yang kawin sumendo tidak berkewajiban mengikuti tempat kediaman suaminya atau keluarga suaminya. Hanya dengan izin yang khas orang Minangkabau boleh melakukan perkawinan endogam, yaitu perkawinan antara orangorang sesuku yang disebut kawin pecah periuk ataupun pecah suku, dengan membayar denda karena melanggar syarat exogam (Sudarsono, 1991: 235).

Keluarga inti dalam masyarakat Minang adalah Samande (seibu), sedangkan gabungan dari beberapa samande disebut saparuik (satu perut) yang dihitung sampai lima keturunan dan tinggal dalam satu kampung yang dipimpin oleh seorang panghulu. Pada tingkatan yang lebih besar diistilahkan dengan sesuku. Pada kasus daerah ini juga berlaku sistem seperti ini namun namanya berubah dengan istilah saboltok (satu perut). Saboltok merupakan tingkatan sanak seseorang yang paling jauh, yakni ibu dari nenek. Jadi dalam satu kaum bisa saja terdiri dari 3 baltok. Beberapa baltok ini kemudian membentuk kaum yang dikepalai oleh mamak kaum yang disebut mamak tuo. Pada tingkatan yang lebih tinggi beberapa kaum kemudian membentuk satu kepenghuluan.

Budaya Minangkabau tidak memberikan batasan tegas mengenai pelapisan sosial, untuk membedakannya berdasarkan penduduk yang mula-mula membuka daerah dengan penduduk yang datang belakangan. Bagi pendatang, bisa mempunyai hak yang sama dengan penduduk asli setelah mereka mengisi adat, dengan mengaku bermamak kepada salah seorang penduduk asli yang berada di sana, namun mereka tidak berhak menyandang gelar adat yang ada di Minangkabau. 
ljtihad, Jurnal Wacana Hukum Islam dan Kemanusiaan, Volume 17, No. 1, Juni 2017: 85-112

Mengenai istilah kekerabatan, sistem yang dipakai tidak berbeda dengan budaya Minang umumnya, mereka masih mengikuti garis keturunan ibu. Namun sudah mengalami perubahan dari segi bahasa, yaitu dipengaruhi oleh bahasa Mandailing. Sistem pewarisan masih mengikuti nilai-nilai yang ada di Minangkabau. Tujuan dari semua itu pada dasarnya untuk mempertahankan garis keturunan dan penentuan sistem pewarisan.

Sedangkan orang Mandailing mempertahankan hidup clannya dengan bentuk-bentuk perkawinan jujur atau sumendo yang keduanya mempunyai tiga ciri, ialah exogam, patrilokal, dan asymmetris bagi perkawinan jujur, sedangkan bagi perkawinan sumendo sifatnya ialah exogam, matrilokal, dan asymmetris. Sifat exogam di tanah Batak/Mandailing sangat mutlak, yaitu larangan mengawini anggota seclan yang sekali-kali tidak boleh dilangkahai, sehingga tidak ada kemungkinan menurut hukum untuk mengadakan perkawinan endogam. Patrilokal artinya, si isteri berkewajiban bertempat tinggal pada suaminya atau dalam lingkungan keluarga suaminya.

Ciri asymmetris artinya melarang orang kawin, walaupun laki-laki dan perempuan itu tidak semarga, manakala antara keluarga si laki-laki dan keluarga si perempuan telah pernah ada yang disebutnya hubungan mora anak boru, yaitu ketika orang dari marga A telah pernah mengawini perempuan dari marga $\mathrm{B}$, maka kesatuan keluarga dari orang marga A itu yang dinamakannya kesatuan kahangginya sebagai bagian dari clan $\mathrm{A}$, tidak boleh lagi mengawinkan anggota keluarganya yang perempuan kepada kesatuan kahanggi pihak bapak si perempuan marga B tadi. Dalam hal ini maka kahanggi yang bersangkutan dari marga A merupakan anak boru bagi kahanggi bapak si perempuan dari marga B yang terdapat golongan anak borunya dari marga A disebut mora. Akibatnya ialah sekali suatu kahanggi dalam suatu marga berkedudukan sebagai mora terhadap suatu kahanggi dari marga lain, maka hubungan kekeluargaan karena perkawinan tersebut harus dipertahankan, dalam arti bahwa pihak yang telah memberikan isteri kepada pihak yang lain tidak lagi dibolehkan untuk sebaliknya menerima isteri dari pihak lain itu.

Golongan yang memberikan isteri dinamakan pihak mora, sedangkan golongan yang menerima isteri dinamakan pihak anak boru. Sistem perkawinan asymmetris di kalangan orang Batak/Mandailing tidak dapat dilakukan hanya antara dua kahanggi yang berlainan marga, tetapi hanya mungkin bila ada lebih dari dua kahanggi yang berlainan marga. Karena batas 
paling rendah bagi pengertian "lebih dari dua" ialah tiga, maka orang Batak menamakan susunan masyarakatnya yang berdasarkan perkawinan asymmetris dalian natolu.

Perkawinan di masyarakat Mandailing dikenal dengan nama perkawinan manjujur, bersifat eksogami patriarchat, artinya setelah perkawinan pihak wanita meninggalkan clannya dan masuk ke clan suaminya dan suaminya menjadi kepala keluarga, serta anak-anak yang dilahirkan dari perkawinan itu akan mengikuti clan (marga) bapaknya.

Jujur maksudnya untuk menjaga keseimbangan dari pihak keluarga wanita atas hilangnya seorang anggota keluarganya yang masuk menjadi anggota keluarga suami. Pada dasarnya benda yang akan diberikan sebagai jujur berupa mas kawin sebagai bantuan melengkapi keperluan pihak perempuan untuk barang bawaannya ataupun untuk tambahan biaya pesta.

Satu hal yang menarik di daerah Rao ini adalah adanya pemakaian marga di belakang nama seseorang sebagaimana di daerah budaya Batak. Namun marga tersebut tidak sama pengertiannya dengan marga yang ada di Sumatera Utara. Pemakaian marga tersebut hanya untuk memberitahukan bahwa mereka adalah orang Mandailing. Ketika mereka ditanya apakah mereka orang Mandailing, mereka pada umumnya tidak mengakui hal tersebut, mungkin ini merupakan salah satu strategi agar mereka dapat menyesuaikan diri di dalam lingkungan tempat tinggal mereka yakni di Rao.

Adat perkawinan yang berlaku sama halnya dengan adat Minang pada umumnya. Namun sebagai akibat dari pertemuan dua budaya yang berbeda, adat perkawinan umumnya dilaksanakan dengan adat Minang, Mandailing, atau modifikasi keduanya. Dengan demikian ada tiga jenis upacara adat perkawinan yang berlaku yaitu; (1) Adat Perkawinan Sumando. Pada adat perkawinan sumando ini sama halnya dengan adat Minang umumnya, yaitu bauluabajawek, baimbang-batarimo, laki-laki datang ke rumah perempuan; (2) Adat Perkawinan Serikat. Adat perkawinan ini terjadi apabila terdapat suatu persetujuan antara laki-laki dan perempuan yang tidak boleh dilarang. Perkawinan ini terjadi antara laki-laki Minang dengan perempuan Mandailing. Pada perkawinan ini, ketentuan melamar dan adat menetap setelah menikah tergantung pada kesepakatan kedua belah pihak, namun cendrung bersifat neolokal. Sedangkan suku anak diakui sebagai orang Minang yang didasarkan pada suku si ayah, namun tidak mewarisi sako karena ibunya bukan orang Minang; (3) Adat Perkawinan Menjujur. Pada perkawinan jujuran ini perempuan dibawa ke tengah-tengah keluarga suami, yang 
ljtihad, Jurnal Wacana Hukum Islam dan Kemanusiaan, Volume 17, No. 1, Juni 2017: 85-112

dimaksud untuk membukakan pintu yang tertutup dengan syarat adanya kesepakatan dalam kaum.

Berdasarkan hasil wawancara dengan Dewi Aprimayanti, Salvi Nova dan Rini menyatakan bahwa setiap perkawinan antara suku Mandailing dan Minang di Rao sangat tergantung dengan perundingan dan kesepakatan kedua belah pihak keluarga calon suami isteri untuk menggunakan sistem perkawinan dan kekerabatan yang dipakai (Dewi dkk, wawancara, 2 April 2016).

Nasbin Panyahatan juga mengemukakan bahwa dalam pelaksanaan perkawinan antara orang Mandailing dengan orang Minang tergantung dengan kesepakatan kedua belah pihak keluarga dan pemuka adat, tetapi biasanya selalu memakai perkawinan adat menjujur. Menjujur ini biasanya dengan memberikan sejumlah uang kepada keluarga laki-laki, dan bahkan terkadang ditambah dengan emas tergantung dengan kondisi keuangan (Panyahatan, wawancara, 12 Juli 2016).

Ahmad Hamidi mengungkapkan, pemberian uang berupa jujuran selalu diberikan. Seandainya uang menjujur ini tidak diberikan terkadang (sekitar $3 \%$ ) perkawinan bisa tidak terlaksana. Tetapi untuk sekarang sangat tergantung dengan kesepakatan kedua belah pihak, dan bahkan perkawinan antara orang Mandailing dengan suku Minang, ada yang tidak memberikan uang menjujur (Hamidi, wawancara, 2 Juni 2016).

Hamidi lebih lanjut menyatakan sesuai dengan kebiasaan adat Mandailing, sebelum perkawinan dilaksanakan calon pengantin yang bukan orang Mandailing dimasukkan ke dalam masyarakat Mandailing agar mempunyai marga. Seorang pria Minang yang akan menikah dengan wanita Mandailing di Rao terlebih dahulu pria tadi diberikan marga, begitupula sebaliknya jika perempuan Minang dengan laki-laki Mandailing, karena marga merupakan lambang identitas dan penghubung sekaligus untuk mengetahui kedudukannya di dalam kekerabatan berdasarkan dalihan natolu. Ada hal yang menarik menurut penulis bahwa 'banyak' masyarakat suku Mandailing di Rao Pasaman yang tidak menggunakan marga di belakang namanya, padahal sebenarnya mereka memiliki marga.

Di antara tujuan perkawinan yang dilakukan secara adat menjujur ini agar suami bertanggungjawab penuh terhadap anak dan isterinya. Di samping itu tidak memutuskan hubungan kekeluargaan dengan keluarga orang tuanya dan masih tetap sebagai mamak dalam kerabatnya.

Banyak juga di belakang nama seseorang disertai dengan nama marga, dari marganya jelas berasal dari Batak, tepatnya dari Tapanuli Selatan. Namun, ia tidak lahir di Tapanuli, 
tapi di daerah yang dikelilingi Bukit Nan Tujuh, Pasaman. Ia lahir dari bapak asal Batak, dan ibu asal Minang. Dalam adat, kebanyakan yang seperti ini menurut ajaran Tapanuli, dengan suku Siregar umpamanya, karena itu menggunakan sistem patrilineal.

Di tempat yang sama ada perempuan Minang yang kawin dengan orang Jawa. Perkawinannya menghasilkan beberapa orang anak. Anak-anaknya bersuku Tanjung, seperti dirinya, dan dalam tradisi adat Minangkabau, mengikuti sistem kekerabatn matrilineal.

Dalam hukum waris adat Mandailing meliputi aturan-aturan dan keputusan-keputusan hukum yang bertalian dengan proses penerusan dan peralihan atau perpindahan harta kekayaan, baik materiil maupun immateriil dari satu generasi ke generasi berikutnya.

Pewarisan dalam adat Mandailing mencangkup 3 (tiga) yang diutamakan dalam ada, yaitu; (1) Memakai hukum adat sebagai tombak pertama dalam menentukan waris; (2) Memakai hukum Islam, sebab dalam suku Mandailing sudah memeluk agama Islam, maka mereka memakai hukum Islam dalam pewarisan; (3) Memakai hukum nasional, sebab bila hukum adat dan hukum Islam tidak ingin dipakai maka mereka memakai hukum nasional.

Dalam pembagian warisan dalam suku Mandailing yang memiliki waris di bagi atas 3 (tiga), yaitu; (1) Anak laki-laki tertua; (2) Anak laki-laki termuda; (3) Anak laki-laki sulung dan bungsu.

Hambatan dalam waris adat Mandailing adalah anak tidak mewarisi dari salah seorang di antara orang tuanya yang tetap tinggal dalam kerabatnya, sedangkan anak-anak tidak masuk di dalamnya. Hambatan lain bagi anak yang dengan perkawinannya berakibat bahwa anak yang kawin tersebut dibebaskan dari kekerabatan. Seperti anak perempuan dengan perkawinan keluar dari kerabat ayahnya, sehingga ia tidak dapat menuntut hak mawaris tanpa wasiat.

Namun adat Mandailing yang sudah mengalami perubahan dikarenakan dalam adat tersebut sudah berbaur dengan agama. Sehingga dalam adat Mandailing hukum yang menetapkan dalam waris adalah memakai hukum Islam. Walaupun lebih banyak laki-laki yang mendapat waris seperti halnya hukum adat, namun dari pihak perempuan pun mendapat bagian dalam waris yang telah ditentukan dalam hukum Islam.

Menurut bapak Ali Akbar, tokoh masyarakat Mandailing di Rao, dengan perkembangan zaman dan didukung dengan adanya perkawinan beda suku antara suku Mandailing dengan 
ljtihad, Jurnal Wacana Hukum Islam dan Kemanusiaan, Volume 17, No. 1, Juni 2017: 85-112

suku Minang atau suku Jawa maka telah terjadi pergeseran sistem pewarisan di dalam masyarakat. Sistem pewarisan yang semula memakai sistem pewarisan patrilineal berobah menjadi sistem matrineal (Ali, wawancara, 12 April 2016). Dengan sistem parental yang mendapatkan harta warisan tidak hanya anak laki-laki tetapi anak-anak perempuan juga mendapatkannya. Ketika terjadi perbedaan pendapat dalam menyelesaikan pembagian warisan, maka persoalan tersebut diselesaikan oleh tokoh adat di mana suami isteri itu bertempat tinggal, bukan tokoh adat kedua suku yang berbeda dari suami isteri tersebut, karena persoalan ini bukan persoalan syiqaq dalam perkawinan suami isteri. Jika terjadi perselisihan antara suami isteri yang berbeda suku tersebut, maka perselisihan itu diselesaikan oleh tokoh adat/ninik mamak kedua belah pihak suami isteri tersebut. Sedangkan perselisihan dalam persoalan pembagian kewarisan diselesaikan oleh tokoh adat atau ninik mamak di mana suami isteri tersebut bertempat tinggal.

Seandainya perselisihan dalam pembagian warisan tersebut tidak bisa diselesaikan secara kekeluargaan walaupun sudah dibantu oleh tokoh adat di mana mereka bertempat tinggal, seperti perempuan Minang yang menikah dengan laki-laki Mandailing, dalam hal ini diselesaikan oleh ninik mamak Minang, begitupula sebaliknya maka ada yang meminta bantuan penyelesaiannya ke Kantor Urusan Agama (KUA) setempat untuk meminta bantuan dalam membagi harta warisan tersebut. Jika tidak bisa juga diselesaikan dengan bantuan yang telah disebutkan di atas, baru diajukan perselisihan dalam pembagian harta warisan dan perkara tersebut ke Pengadilan Agama Lubuk Sikaping.

Selanjutnya bapak Ali Akbar mengungkapkan, banyak juga yang membagi harta warisan dari perkawinan orangtua yang berbeda suku tersebut dengan sistem kewarisan Islam (menurut ilmu faraid) (Ali, wawancara, 2 Juni 2016), tetapi menurut Hamidi kadang tergantung juga dengan kondisi keluarga laki-laki di keluarga tersebut . Jika anak laki-laki memiliki kelebihan dari sisi ekonomi sedangkan anak perempuan kurang dari sisi ekonomi daripada anak laki-laki, maka banyak juga anak laki-laki dari perkawinan orangtua yang berbeda suku tersebut memberikan bagian harta warisannya kepada saudara perempuannya, dengan arti kata anak laki-laki tidak mengambil harta warisan yang ditinggalkan oleh orang tua mereka yang berbeda suku tersebut (Hamidi, wawancara, 3 Juli 2016). 


\section{Penutup}

Pada bagian ini akan penulis kemukakan tentang kesimpulan dan saran berdasarkan penelitian yang telah dilakukan. Secara garis besar masyarakat Rao yang dihuni oleh etnik Minangkabau dan etnik Mandailing dalam system kekerabatan terdapat beberapa sifat, yakni golongan masyarakat yang bersifat kebapakan (patrilineal), masyarakat yang bersifat keibuan (matrilineal), dan golongan yang bersifat kebapak ibuan (parental). Kekeluargaan yang bersifat parental merupakan sifat yang paling dominan di daerah multi etnik Rao ini sebagai sebuah system kekerabatan baru yang dibangun dalam proses interaksi sosial mereka selama ratusan tahun.

Adapun dalam system pembagian waris, masyarakat adat perbatasan terutama daerah Rao telah menerapkan beberapa jenis pembagian waris yaitu: Pertama, Masyarakat adat perbatasan Rao memakai hukum adat baru system parental yang memadukan dua adat sebagai tombak pertama dalam menentukan waris Kedua, mereka memakai hukum Islam, sebab dalam suku Minangkabau dan Mandailing adalah pemeluk agama Islam, maka mereka memakai hukum Islam dalam pewarisan. Ketiga, mereka memakai hukum nasional, sebab bila hukum adat dan hukum Islam tidak ingin dipakai maka mereka memakai hukum nasional.

\section{Daftar pustaka}

Anwar, Chairul. Hukum Adat Indonesia Meninjau Hukum Adat Minangkabau. Cet. ke-1. Jakarta: P'T Rineka Cipta, 1997.

Bachtiar, Maryati. "Hukum Waris Islam Dipandang Dari Perspektif Hukum Berkeadilan Gender" dalam Jurnal Ilmu Hukum Vol. 3, No.1.

Benda Backmann Franz von. Properti dan Kesinambungan Sosial. Jakarta: Grasindo, 2006.

Bungin, Burhan. Aktualisasi Metodologis ke Metodologi Penelitian Kualitatif, Arah Ragam Varian Kontemporer. Jakarta : PT RajaGrafindo Persada, 2008.

Bushar, Muhammad. Pokok-Pokok Hukum Adat. Cet. ke-5. Jakarta: PT Pradnya Paramita, 1991.

Darussamin, Zikri. Interaksi Hukum Islam dan Adat (Studi Pelaksanaan Kewarisan Masyarakat Melayu di Daerah Siak. Disertasi. Medan: Universitas Sumatera Utara, 2010.

Fatma, Marlis. "Karakteristik Masyarakat Rao", dalam Padang Ekspress, Minggu, 20 September 2011.

Hadler, Jeffrey. Sengketa Tiada Putus, Matriakat, Reformisme Islam, dan Kolonialisme di Minangkabau. Jakarta: Freedom Institute, 2010. 
ljthad, Jurnal Wacana Hukum Islam dan Kemanusiaan, Volume 17, No. 1, Juni 2017: 85-112

Hadikusuma, Hilman. Hukum Perkaninan Adat. Bandung: Alumni, 1977.

Hanum, Farida. Pelaksanaan Hukum Waris Islam dalam Lingkungan Adat Mandailing Godang (Studi pada Mandailing Godang Kabupaten Madina). Tesis. Medan: Universitas Sumatera Utara, 2007.

Huda, Yasrul. Islamic Law Versus Adat: Debate about Inheritance Law and the Rise Capitalism in Minangkabau. Padang: al-Moenir Publishing House, 2003.

Kamaluddin, Syafruddin Halimy. Adat Minangkabau dalam Perspektif Hukum Islam. Cet. ke-1. Padang: Hayfa Press, 2005.

Kemal, Iskandar. Pemerintaban Nagari Minangkabau dan Perkembangannya Tinjauan Tentang Kerapatan Adat. Cet. ke-1. Yogyakarta: Graha Ilmu, 2009.

Mardani. Hukum Kewarisan Islam di Indonesia. Cet. Ke-1. Jakarta: Rajawali Pers, 2014.

Moleong, Lexy J. Metode Penelitian Kualitatif. Bandung : PT Remaja Rosda Karya, 1997.

Mulyani, Muslim. Figh Mawaris. Bukittinggi: STAIN Bukittinggi Press, 2006.

Hasan, Ramli, Fauzi Ahmad, dan Agus Salim. Tuanku Rao dan Rakyat Rao Melawan Penjajah. Yogyakarta: Majalah Suara Muhammadiyah Yogyakarta Kerjasama dengan Pemerintah Kabupaten Pasaman Sumatera Barat, 2009.

Riduwan. Belajar Mudab Penelitian untuk Guru-Karyawan dan Peneliti Pemula. Bandung: Alfabeta, 2007.

Ritonga, Parlaungan dan Ridwan Azhar. Sistem Pertuturan Masyarakat Tapanuli Selatan. Medan: PT. Yandira Agung, 2002.

Rofiq, Ahmad. Fiqh Mawaris. Cet. Ke-5. Jakarta: Rajawali Pers, 2012.

Rozi, Syafwan. "Negosiasi Islam Kultur Dalam Gerakan Paderi Rao Sumatera Tengah (18201833)" dalam Kalam: Jurnal Studi Agama dan Pemikiran Islam, Vol. 6 No. 1 Juni, 2012.

Satriyo, Wicaksosno. Hukum Waris. Jakarta: PT Gramedia, 2011.

Setiady, Tolib. Intisari Hukum Adat Indonesia dalam Kajian Kepustakaan. Cet. Ke-3. Bandung: Alfabeta, 2013.

Sudarsono. Hukum Kekeluargaan Nasional. Cet. Ke-1. Jakarta: PT Rineka, 1991.

Sudiyat, Imam. Hukum Adat Sketsa Asas. Yogyakarta: Liberty Yogyakarta, 1978.

Suparman, Eman. Hukum Waris Indonesia dalam Perspektif Islam, Adat dan BW. Bandung: PT Refika Aditama, t.t.

Syarifuddin, Amir. Pelaksanaan Hukum Kewarisan Islam dalam Lingkungan Adat Minangkabau. Jakarta: Gunung Agung, 1984.

Tarigan, Azhari Akmal. Pelaksanaan Hukum Waris Pada Masyarakat Karo Muslim Di Kabupaten Karo. Disertasi. Medan: Universitas Sumatera Utara, 2010.

Umam, Dian Khairul. Fiqih Mawaris. Bandung: Pustaka Setia, 2006. 